\title{
Endotoxin at low doses stimulates pituitary GH whereas it decreases IGF-I and IGF-binding protein-3 in rats
}

\author{
T Priego, M Granado, I Ibáñez de Cáceres, A I Martín, \\ M A Villanúa and A López-Calderón \\ Departamento Fisiología, Facultad de Medicina, Universidad Complutense, 28040 Madrid, Spain \\ 'Departamento Ciencias Morfológicas y Fisiología, Universidad Europea, 28670 Madrid, Spain \\ (Requests for offprints should be addressed to A López-Calderón; Email: ALC@med.ucm.es)
}

\begin{abstract}
While it is well known that sepsis inhibits serum IGF-I and its gene expression in the liver, the effect on pituitary $\mathrm{GH}$ and IGF-binding protein-3 (IGFBP-3) is poorly understood. The GH-IGF-I-IGFBP-3 response to different doses of lipopolysaccharide (LPS) administration has been investigated in adult male rats. Two experiments were performed, administration of low doses of LPS $(5,10$, 50 and $100 \mu \mathrm{g} / \mathrm{kg})$ and high doses of LPS (100, 250, 500 and $1000 \mu \mathrm{g} / \mathrm{kg}$ ). Rats received two i.p. injections of LPS (at $1730 \mathrm{~h}$ and $0830 \mathrm{~h}$ the following day) and were killed $4 \mathrm{~h}$ after the second injection. LPS administration induced a biphasic response in serum concentrations of $\mathrm{GH}$, with an increase at the $10 \mu \mathrm{g} / \mathrm{kg}$ dose, followed by a decrease at higher doses (100 $\mu \mathrm{g} / \mathrm{kg}$ on up). Pituitary GH mRNA was also increased by the administration of 10 and $50 \mu \mathrm{g} / \mathrm{kg}$ LPS, whereas at higher doses LPS did not modify pituitary GH mRNA. We also analyzed the GH response to LPS in primary pituitary cell cultures. When exposed to LPS, in the culture medium, there was an increase in $\mathrm{GH}$ release at the concentration of 0.1 and $10 \mathrm{ng} / \mathrm{ml}$, whereas more
\end{abstract}

concentrated LPS did not modify GH release. Serum concentrations of IGF-I declined in a dose-dependent fashion after LPS administration in the rats injected with $10 \mu \mathrm{g} / \mathrm{kg}$ LPS on up. This decrease is secondary to modifications in its synthesis in the liver, since endotoxin injection decreased both IGF-I and its mRNA in the liver. The liver GH receptor mRNA was also decreased by LPS administration, but only in the animals injected with high LPS doses. There was a decrease in both the IGFBP-3 serum levels and its gene expression in the liver with all LPS doses studied. These data suggest a biphasic LPS effect on pituitary GH, a stimulatory effect at low doses and an inhibitory effect at higher doses, whereas it has a clear inhibitory effect on IGF-I and IGFBP-3 synthesis in the liver. The decrease in liver IGFBP-3 mRNA and in serum concentrations of IGFBP-3 in the rats injected with LPS may contribute to the decrease in serum concentrations of IGF-I.

Journal of Endocrinology (2003) 179, 107-117

\section{Introduction}

Sepsis, inflammation and critical illnesses are catabolic states that result in a series of changes characterized by protein hypercatabolism and negative nitrogen balance. These situations are associated with several neuroendocrine changes that include an increase in serum concentrations of glucocorticoids together with a decrease in anabolic hormones. A decrease in serum concentrations of insulin-like growth factor-I (IGF-I) has been described in different inflammatory conditions in humans and experimental animals (Dahn et al. 1988, Fan et al. 1994). However, the precise mechanism responsible for this inhibition is not well known.

Lipopolysaccharide (LPS) is a component of Gramnegative bacteria, and its administration triggers the sepsis response (Karima et al. 1999). LPS administration decreases the serum concentrations of IGF-I in humans (Lang et al. 1997) and experimental animals (Fan et al. 1994). We have previously observed a decrease in serum concentrations of IGF-I $3 \mathrm{~h}$ after a low dose $(25 \mu \mathrm{g} / \mathrm{kg})$ LPS injection (Soto et al. 1998). Although this effect seems to be due to an inhibition of its synthesis in the liver, it is necessary to administer a much higher LPS dose (2500 or $7500 \mu \mathrm{g} / \mathrm{kg}$ ), and to measure liver IGF-I mRNA $10 \mathrm{~h}$ after LPS administration in order to find a decrease in liver IGF-I mRNA (Defalque et al. 1999).

Decreased growth hormone $(\mathrm{GH})$ secretion has been reported to be responsible for the LPS-induced decrease in IGF-I in rodents, but GH resistance has been described in LPS-injected rats mediated by the loss of liver GH receptor (GHR) (Defalque et al. 1999). However, an increase in the number of GHRs in the liver has also been reported in septic rats (O'Leary et al. 2000). 
In rodents, the GH response to LPS or sepsis is more variable than the IGF-I response, since both a decrease (Kasting \& Martin 1982, Fan et al. 1994, Soto et al. 1998) and the absence of modifications (Defalque et al. 1999, O'Leary et al. 2000) in circulating levels of GH have been described in septic rats. The difference may reside in pulsatile secretion of this hormone. However, in other species such as in humans (Lang et al. 1997), sheep (Daniel et al. 2002) and pigs (Hevener et al. 1997), LPS administration stimulates $\mathrm{GH}$ release, albeit it inhibits serum concentrations of IGF-I. Discrepancies can be due to the LPS dose; in humans and sheep the most frequently used LPS dose is less than $1 \mu \mathrm{g} / \mathrm{kg}$ (Coleman et al. 1993, Lang et al. 1997, Briard et al. 2000). In contrast, in rodents the effect of LPS on the somatotropic axis has been studied employing high LPS doses $(1-15 \mathrm{mg} / \mathrm{kg}$ ), which also induce endotoxic shock.

LPS administration decreases serum concentration of the main IGF-I binding protein, IGF binding protein-3 (IGFBP-3), by a mechanism independent of $\mathrm{GH}$ and IGF-I (Priego et al. 2003). We have previously reported that LPS administration to Lewis rats decreased serum concentrations of IGF-I, but liver IGF-I or its mRNA in the liver was not modified (Priego et al. 2002); these data suggest that LPS may increase IGF-I turnover in serum.

In this study we analyzed the effect of different LPS doses on pituitary GH gene expression and on serum concentrations of GH, IGF-I and IGFBP-3, as well as the GHR, IGF-I and IGFBP-3 gene expression in the liver. Since we previously found a significant decrease in liver GHR, IGF-I and IGFBP-3 mRNA after two LPS injections of $1 \mathrm{mg} / \mathrm{kg}$ (Priego et al. 2002), in this study we have analyzed the GH-IGF-I-IGFBP-3 response to two LPS injections, at different doses, in order to identify the primary site of inhibition of the somatotropic axis during endotoxin administration. As the pituitary GH response to LPS can be influenced by the LPS effect on circulating levels of IGF-I, the pituitary GH release in vitro after LPS administration was also tested. We describe the lack of correlation between pituitary GH and the IGF-IIGFBP-3 system in rats injected with a low LPS dose, and the possible role of LPS-induced decrease in circulating IGFBP-3 in decreasing the serum concentrations of IGF-I.

\section{Materials and Methods}

\section{Animals}

Adult male Wistar rats (200-250 g body weight) were used for the in vivo and in vitro studies. They were purchased from Harlan (Barcelona, Spain), and maintained under standardized conditions of temperature $\left(20-22^{\circ} \mathrm{C}\right)$ and light (lights on from 0730 to $1930 \mathrm{~h}$ ), with free access to food and water. The procedures followed the guidelines recommended by the European Union for the care and use of laboratory animals.

\section{LPS administration}

Rats were injected with different low doses $(0,5,10,50$ and $100 \mu \mathrm{g} / \mathrm{kg}$ ) and high doses $(100,250,500$ and $1000 \mu \mathrm{g} / \mathrm{kg}$ ) of LPS (serotype 055:B5; Sigma Chemical Co, St Louis, MO, USA) in $250 \mu$ l sterile saline i.p. at $1730 \mathrm{~h}$ and at $0830 \mathrm{~h}$ the following day. All animals were killed by decapitation at $1230 \mathrm{~h}$ in a separated room, within $30 \mathrm{~s}$ after having been removed from their cages. Trunk blood was collected in cooled tubes, allowed to clot, centrifuged and the serum stored at $-20{ }^{\circ} \mathrm{C}$ until $\mathrm{GH}$, IGF-I and IGFBP-3 analyses were performed. Immediately after decapitation the neurointermediate lobe of the pituitary was removed and the anterior pituitary lobe was frozen in liquid nitrogen and stored at $-80{ }^{\circ} \mathrm{C}$ until RNA extraction was performed. The liver was removed, dissected, frozen in liquid nitrogen and stored at $-80{ }^{\circ} \mathrm{C}$ until RNA extraction was performed.

\section{Cell cultures}

Pituitaries were obtained within $1 \mathrm{~min}$ of killing by decapitation, the neurointermediate lobes were removed, and the anterior lobes were dissected into small pieces and enzymatically dispersed in dissociating buffer containing $0.4 \%$ collagenase type I (Sigma), 0.01\% DNase I (Boehringer Mannheim, Barcelona, Spain) and $50 \mu \mathrm{g} / \mathrm{ml}$ gentamicin sulfate (ICN Biomedicals, Inc., Aurora, OH, USA) for $45 \mathrm{~min}$ at $37^{\circ} \mathrm{C}$ and centrifuged at $260 \mathrm{~g}$. Cell suspension was filtered through a nylon mesh $(100 \mu \mathrm{m})$, centrifuged and washed firstly in sterile cold $\mathrm{Ca}^{2+}$-free buffer $\left(119 \cdot 4 \mathrm{mM} \mathrm{NaCl}, 4 \cdot 8 \mathrm{mM} \mathrm{KCl}, 1.2 \mathrm{mM} \mathrm{KH}_{2} \mathrm{PO}_{4}\right.$ and $25 \cdot 1 \mathrm{mM} \mathrm{NaHCO}, 1 \mathrm{mM}$ EDTA, $20 \mathrm{mM}$ HEPES $\mathrm{pH} 7 \cdot 3$ ), and secondly in sterile cold buffer containing $2 \cdot 6 \mathrm{mM} \mathrm{CaCl}_{2}$ and without EDTA. Cellular viability was estimated by the trypan blue test, and was greater than $96 \%$. Cells were resuspended in culture medium RPMI 1640 supplemented with 10\% fetal bovine serum (Bio-Whittaker Europe, Verviers, Belgium), $50 \mu \mathrm{g} / \mathrm{ml}$ gentamicin sulfate and $2 \mathrm{mM}$ glutamine (Sigma). Cells $\left(10^{5} /\right.$ well in $500 \mu \mathrm{l}$ culture medium) were distributed in 24-well tissue culture plates (Nunc, Roskilde, Denmark) and grown at $37^{\circ} \mathrm{C}$ with $5 \% \mathrm{CO}_{2}$. After 3 days, cells were washed and incubated for $4 \mathrm{~h}$ in $250 \mu \mathrm{l}$ serum-free RPMI 1640 containing $0 \cdot 01 \%$ BSA, $50 \mu \mathrm{g} / \mathrm{ml}$ gentamicin sulfate and $2 \mathrm{mM}$ glutamine. LPS was dissolved in the assay medium at a $0.1 \mathrm{mg} / \mathrm{ml}$ stock solution. The experiments were performed twice.

\section{Hormone determination}

Concentrations of $\mathrm{GH}$ in serum and in culture medium were measured by an RIA using reagents provided by Dr Parlow of the National Institute of Diabetes, Digestive and Kidney Diseases (NIDDK) National Hormone and Pituitary Program, NIH, Bethesda, MD, USA. Levels of 
GH were expressed in terms of NIDDK rat-RP-2 standard. The GH detection level was $10 \mathrm{pg}$, and the intraassay coefficient of variation was 3\%. IGF-I concentrations were measured by a double-antibody RIA using the antibody NIDDK UB2-495, a gift from Drs Underwood and Van Wik, and it is distributed by the Hormone Distribution Program of NIDDK through the National Hormone and Pituitary Program. Serum IGF-I binding proteins (IGFBPs) were removed by an acid-ethanol extraction, liver samples were homogenized in $1 \mathrm{M}$ acetic acid, boiled for $20 \mathrm{~min}$, and lyophilized (López-Calderón et al. 1999). Levels of IGF-I were expressed in terms of human IGF-I from Gropep Ltd (Adelaide, Australia). The intra-assay coefficient of variation was $8 \%$. All necessary comparisons between test and control animals were carried out within the same assay.

\section{Western ligand blot}

Serum samples $(2 \cdot 5 \mu \mathrm{l})$ were subject to $1 \%$ SDS-12.5\% acrylamide gel non-reducing electrophoresis, and electrotransferred to nitrocellulose membranes (Hybond-C extra; Amersham). The membranes were dried and blocked for $1 \mathrm{~h}$ with $5 \%$ non-fat dry milk, $0 \cdot 1 \%$ Tween (Sigma) in Tris-buffered saline. Membranes were probed overnight at $4{ }^{\circ} \mathrm{C}$ with ${ }^{125}$ I-IGF-I $\left(5 \times 10^{5}\right.$ c.p.m. $\left./ \mathrm{ml}\right)$. The nitrocellulose sheets were then washed, dried and blots were exposed at $-80{ }^{\circ} \mathrm{C}$ to X-ray film (Kodak X-Omat AR; Eastman Kodak, Rochester, NY, USA) and two intensifying screens for 1-5 days according to the signal obtained. Autoradiographs were analyzed by densitometric scanning using a PC-Image VGA24 (Foster Findlay Associates Ltd, Newcastle upon Tyne, Tyne and Wear, UK) program for Windows. The density of the IGFBP bands in each lane was expressed as the percentage of the mean density of sera from control rats injected with saline.

\section{RNA extraction and Northern blot analysis}

Total RNA extraction was performed with a kit (Ultraspec RNA; Biotecx Laboratories, Houston, TX, USA) following the manufacturer's instructions. The integrity and the concentration of the RNA were confirmed using agarose gel electrophoresis. For Northern blotting, $30 \mu \mathrm{g}$ denatured RNA from livers and $5 \mu \mathrm{g}$ from pituitaries were separated by formaldehyde-agarose gel electrophoresis, transferred to nylon membranes (Hybond$\mathrm{N}+$; Amersham) by overnight capillary blotting and fixed by UV crosslinking (Fotodyne, Hartland, WI, USA).

IGF-I and GHR mRNA hepatic levels were measured by Northern blot hybridization using riboprobes (Roberts et al. 1987, Baumbach et al. 1989). The rat IGF-I and GHR probes were derived from a HindIII fragment of the pGEM-3 plasmid vector (Promega, Madison, WI, USA). ${ }^{32} \mathrm{P}-$ labeled RNA antisense probes were generated from linearized plasmid with $\left[\alpha-{ }^{32} \mathrm{P}\right] \mathrm{CTP}$ (Nuclear Ibérica,
Madrid, Spain) and T7 RNA polymerase (Roche Molecular Biochemicals, Barcelona, Spain).

Prehybridization was performed for $30 \mathrm{~min}$ at $68^{\circ} \mathrm{C}$ in ULTRAhyb buffer (Ambion, Austin, TX, USA) followed by hybridization for $16 \mathrm{~h}$ at the same temperature with $1 \times 10^{6}$ c.p.m./ml IGF-I labeled riboprobe or $3 \times 10^{6}$ c.p.m./ml GHR labeled riboprobe, in the same buffer. The membranes were washed twice with $2 \times$ SSC, $0 \cdot 1 \%$ SDS at $68^{\circ} \mathrm{C}$ for $10 \mathrm{~min}$, and twice with $0.1 \times$ SSC, $0 \cdot 1 \%$ SDS at $68^{\circ} \mathrm{C}$, also for $10 \mathrm{~min}$.

The rat GH cDNA probe was the HindIII fragment of the pRGH-1 (Peter et al. 1977). The rat IGFBP-3 cDNA probe encodes the IGFBP-3 protein mRNA (Albiston \& Herington 1990); the probe was obtained by cutting the PEGEM 4Z plasmid vector using EcoR1 and HindIII. Prehybridization was performed for $30 \mathrm{~min}$ in ULTRAhyb buffer, followed by hybridization at $42{ }^{\circ} \mathrm{C}$ for $16 \mathrm{~h}$ with $0.5 \times 10^{6} \quad$ c.p.m. $/ \mathrm{ml}$ GH cDNA or $3 \times 10^{6}$ c.p.m./ml IGFBP-3 labeled with a random priming DNA labeling kit (DECAprimeTM II; Ambion). The membranes were washed twice with $2 \times$ SSC, $0 \cdot 1 \%$ SDS at $42{ }^{\circ} \mathrm{C}$ for $10 \mathrm{~min}$, and twice with $0 \cdot 1 \times \mathrm{SSC}, 0 \cdot 1 \% \mathrm{SDS}$, also for $10 \mathrm{~min}$ at $42{ }^{\circ} \mathrm{C}$.

To verify loading, control hybridization was performed with a $28 \mathrm{~S}$ DNA probe labeled with $\left[{ }^{32} \mathrm{P}\right] \mathrm{dCTP}$ by random primer. The membranes were exposed at $-80{ }^{\circ} \mathrm{C}$ for $1-4$ days. The intensities of autoradiograph signal levels were measured and expressed as the percentage of the mean intensity of the control group injected with saline.

\section{Statistical analysis}

All data are presented as the means \pm S.E.M. Serum GH data were subject to $\log$ transformation since variances showed a log-normal distribution. Simple linear regression was used to determine correlations between variables. Differences among experimental groups were analyzed by one-way ANOVA. Where there were differences among groups, these were subjected to post-hoc comparisons by using the unpaired Student's $t$-test. Significance was assumed when $P<0 \cdot 05$.

\section{Results}

Figure 1 shows the effect of LPS administration on GH gene expression in the pituitary and on serum concentrations of GH in rats injected with low LPS doses. LPS induced a significant $(P<0 \cdot 05)$ increase in pituitary GH gene expression at the doses of 10 and $50 \mu \mathrm{g} / \mathrm{kg}$ LPS (Fig. 1B). Similarly, serum concentrations of GH was increased $(P<0.05)$ in the group of rats injected with $10 \mu \mathrm{g} / \mathrm{kg}$ LPS (Fig. 1A). However, this stimulatory effect disappeared when the LPS dose was increased, since LPS administration decreased serum concentrations of $\mathrm{GH}$ in the 
A

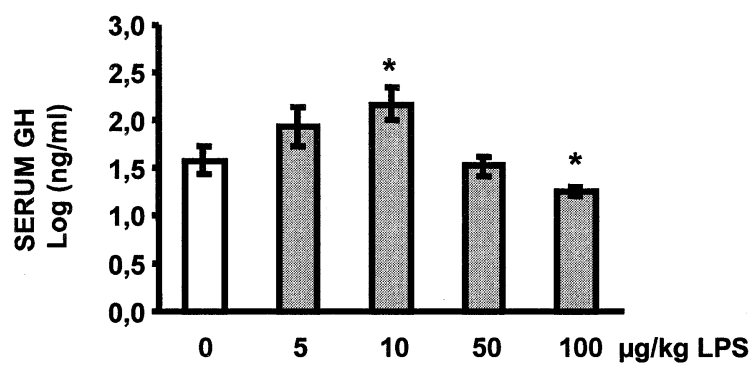

B

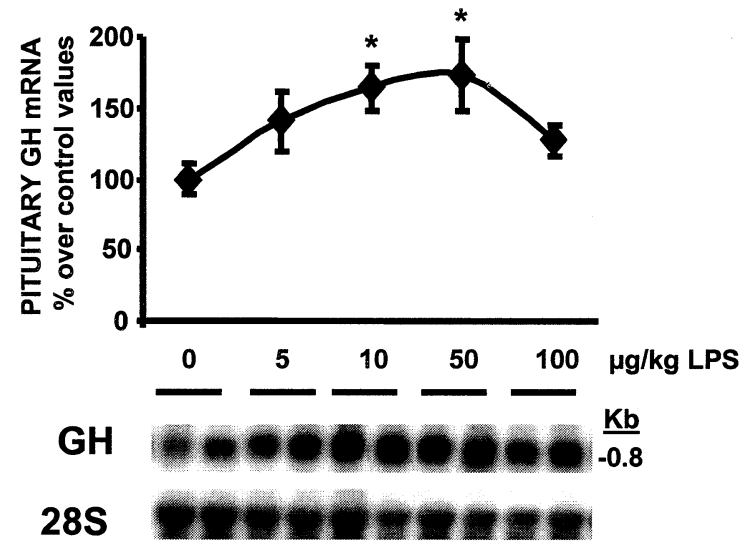

Figure 1 (A) Serum concentrations of $\mathrm{GH}$; there was an increase in serum concentrations of $\mathrm{GH}$ in the rats injected with $10 \mu \mathrm{g} / \mathrm{kg}$, and a decrease in the group of rats injected with $100 \mu \mathrm{g} / \mathrm{kg}$ LPS. Each point represents the mean \pm S.E.M. for 9-12 rats per group. ${ }^{*} P<0.05$ vs control rats injected with saline. (B) Northern blot hybridization and quantification of pituitary $\mathrm{GH}$ mRNA in rats injected with low LPS doses (5-100 $\mu \mathrm{g} / \mathrm{kg}$ ). Pituitary GH mRNA was expressed as the percentage in relation to control values \pm S.E.M. for $6-8$ samples. Autoradiographs of a representative $\mathrm{GH}$ Northern blot hybridization of $5 \mu \mathrm{g}$ pituitary RNA and the 28S ribosomal RNA as load control are shown below. LPS administration increased GH mRNA in rats injected with 10 and $50 \mu \mathrm{g} / \mathrm{kg}$ LPS. Each point represents the mean \pm S.E.M. for $6-8$ rats per group. ${ }^{*} P<0.05$ vs control rats injected with saline.

groups of rats injected with 100-1000 $\mu \mathrm{g} / \mathrm{kg}$ LPS (Figs 1A and $2 \mathrm{~A}$ ). The GH gene expression in the pituitary was not modified by LPS administration at high doses (Fig. 2B), and there was no correlation between the serum concentrations of $\mathrm{GH}$ and its gene expression in the pituitary.

When LPS was added to the pituitary cell cultures, a significant increase in $\mathrm{GH}$ release was also observed at the two lowest concentrations studied $(0 \cdot 1$ and $10 \mathrm{ng} / \mathrm{ml})$, whereas no modifications in $\mathrm{GH}$ release could be observed at higher concentrations (Fig. 3).

The liver GHR mRNA response to LPS administration was not modified by low LPS doses (Fig. 4A), but
A

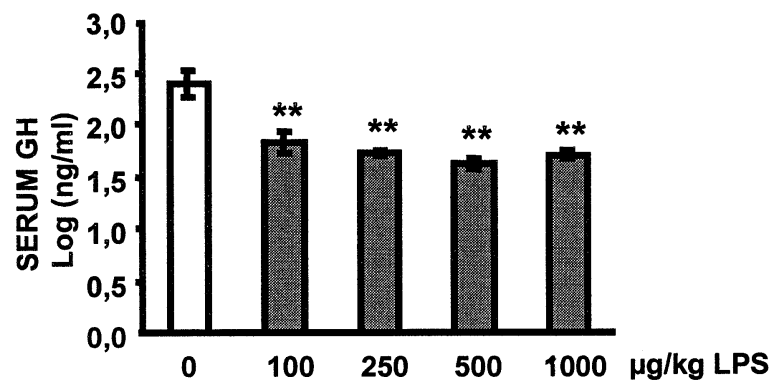

B

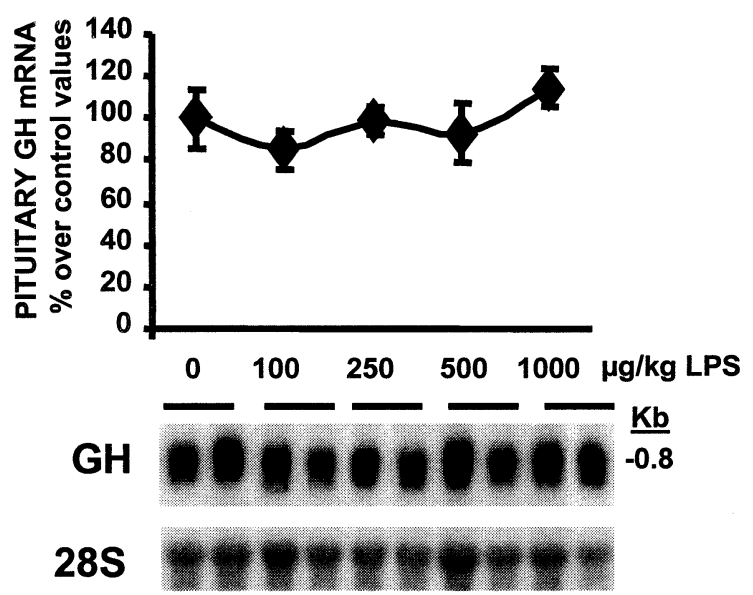

Figure 2 (A) Serum concentrations of $\mathrm{GH}$ in rats injected with high LPS doses. There was a decrease in circulating $\mathrm{GH}$ in all groups of rats injected with LPS. Each point represents the mean \pm S.E.M. for $9-10$ rats per group. ${ }^{* *} P<0.01$ vs control rats injected with saline. (B) Northern blot hybridization and quantification of pituitary GH mRNA in rats injected with high LPS doses $(100-1000 \mu \mathrm{g} / \mathrm{kg})$. Pituitary GH mRNA was expressed as the percentage in relation to control values \pm S.E.M. for $7-8$ samples. Autoradiographs of a representative GH Northern blot hybridization of $5 \mu \mathrm{g}$ RNA and the $28 \mathrm{~S}$ ribosomal RNA as load control are shown below.

when administered at higher doses, LPS administration decreased liver GHR mRNA (Fig. 4B).

The effect of LPS on serum concentrations of IGF-I is shown in Figs 5A and 6A. There was a significant decrease in serum IGF-I levels from the dose of $10 \mu \mathrm{g} / \mathrm{kg}$ until the highest of $1000 \mu \mathrm{g} / \mathrm{kg}$, and this decrease showed a dosedependent effect. LPS-induced decrease in serum concentrations of IGF-I seems to be secondary to its hepatic synthesis, since the liver IGF-I was decreased starting at the dose of $10 \mu \mathrm{g} / \mathrm{kg}$ (Figs $5 \mathrm{~B}$ and $6 \mathrm{~B}$ ). There was a positive correlation between the serum concentrations of IGF-I and the liver IGF-I in both experiments 


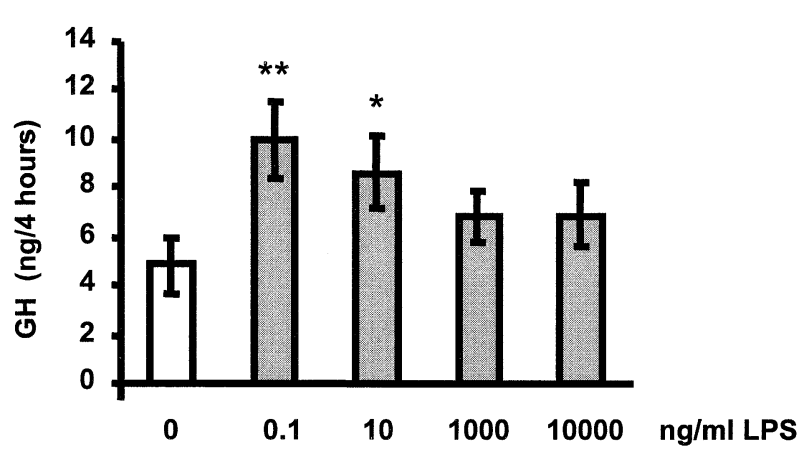

Figure $3 \mathrm{GH}$ concentrations in incubation media from dispersed adenohypophysial cells, after incubation with different LPS concentrations for $4 \mathrm{~h}$. Values are expressed as the mean \pm S.E.M. $(n=9-12) .{ }^{*} P<0 \cdot 01,{ }^{*} P<0 \cdot 05$ vs medium alone.

$\left(r=0 \cdot 638, \mathrm{~F}_{1,40}=31, P<0 \cdot 01\right.$, in the low doses, and $r=0.676, \mathrm{~F}_{1,45}=35, P<0 \cdot 01$, in the high doses). The liver IGF-I mRNA was also decreased in the rats injected with LPS, but this decrease was not statistically significant until the $50 \mu \mathrm{g} / \mathrm{kg}$ LPS dose on up (Figs 5D and 6D). Nevertheless, similarly to the liver IGF-I, the liver IGF-I mRNA correlates with the serum concentrations of IGF-I $\left(r=0 \cdot 65, \mathrm{~F}_{1,32}=23, P<0 \cdot 01\right.$ in the low doses, and $r=0.461, F_{1,33}=8.64, P<0.01$ in the high doses). At all doses studied the LPS-induced decrease in serum concentrations of IGF-I is more dramatic than in liver IGF-I or in liver IGF-I mRNA (e.g. in the rats injected with $1 \mathrm{mg} / \mathrm{kg}$ LPS the decreases were $76 \cdot 3,44$ and $42 \%$ respectively).

LPS administration decreased both the serum concentrations of IGFBP-3 and the liver IGFBP-3 mRNA in all doses studies (Figs 7 and 8). In contrast to the IGF-I data, the LPS-induced decrease was more dramatic in the liver IGFBP-3 mRNA than in the serum concentrations of IGFBP-3 (81 and 46\% decrease in rats injected with $1 \mathrm{mg} / \mathrm{kg}$ LPS). There was a positive correlation between these two variables $\left(r=0.59, \mathrm{~F}_{1,34}=18.1, P<0.01\right)$ in the rats injected with high LPS doses.

\section{Discussion}

Our data show that LPS, at low doses, not only not decreases but stimulates pituitary GH synthesis and secretion. Nevertheless, LPS decreases circulating IGF-I and IGFBP-3 as well as their gene expression in the liver. A direct inhibitory effect of LPS on liver IGF-I and IGFBP-3 gene expression which is independent of pituitary GH is not surprising, since the liver is the first organ that the circulating blood reaches after draining the peritoneum. Then, it seems logical that the liver would be more sensitive than the pituitary to the effect of LPS injected i.p. In addition, a direct inhibitory effect of cytokines on IGF-I and GHR gene expression in liver cell cultures has also been described (Wolf et al. 1996).

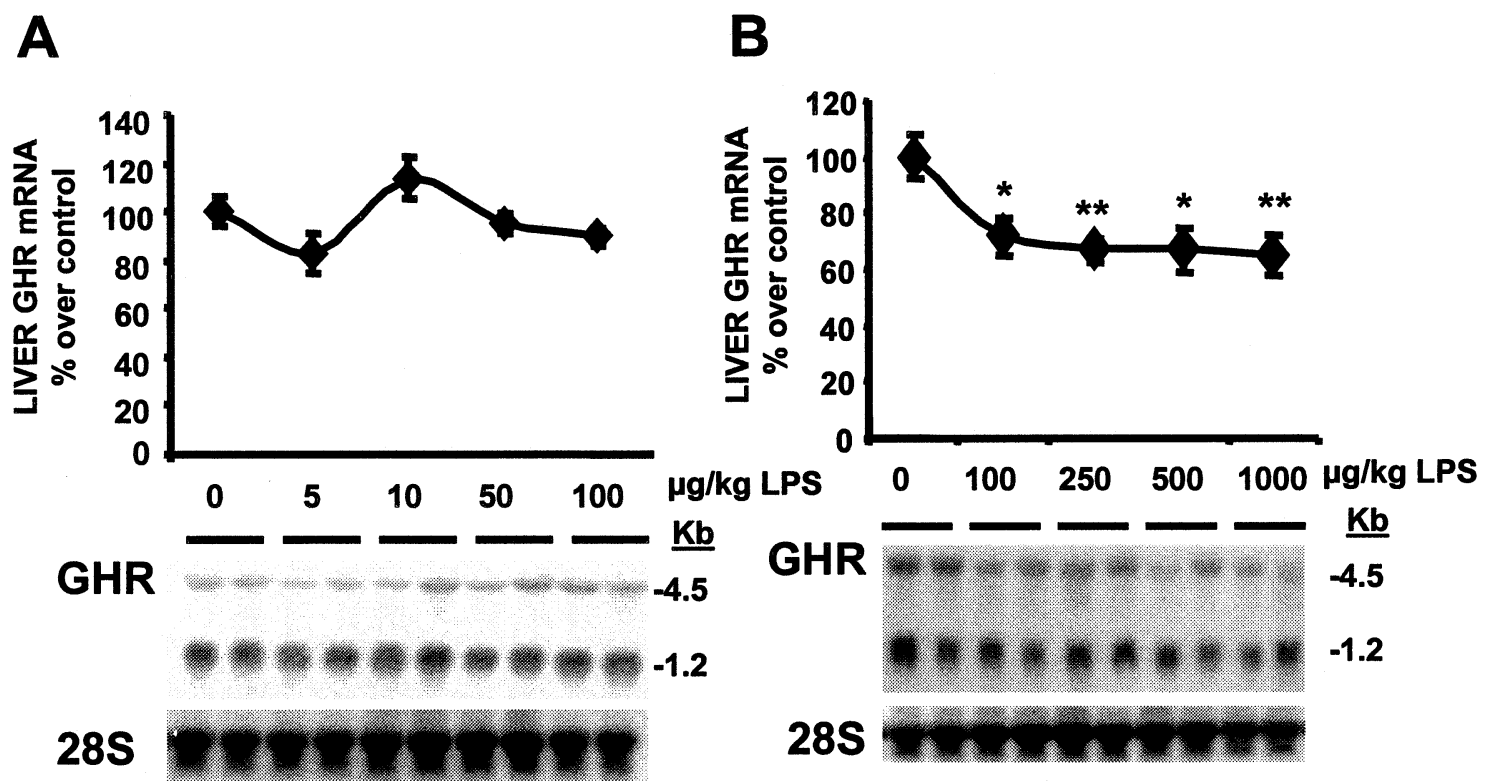

Figure 4 Northern blot hybridization and quantification of liver GHR mRNA in (A) rats injected with low LPS doses $(5-100 \mu \mathrm{g} / \mathrm{kg})$ and in (B) rats injected with high LPS doses (100-1000 $\mu \mathrm{g} / \mathrm{kg})$. Liver GHR mRNA consists of two mRNAs of 4.5 and $1.2 \mathrm{~kb}$; both transcripts were quantified by densitometric analysis and results were expressed as the percentage in relation to control values \pm S.E.M. for 5-8 samples. Autoradiographs of a representative GHR Northern blot hybridization of $30 \mu \mathrm{g}$ RNA and the $28 \mathrm{~S}$ ribosomal RNA as load control are shown below. There was a decrease in liver GHR mRNA in rats injected with high LPS doses. ${ }^{*} P<0 \cdot 05,{ }^{* \star} P<0 \cdot 01$ vs control rats injected with saline. 

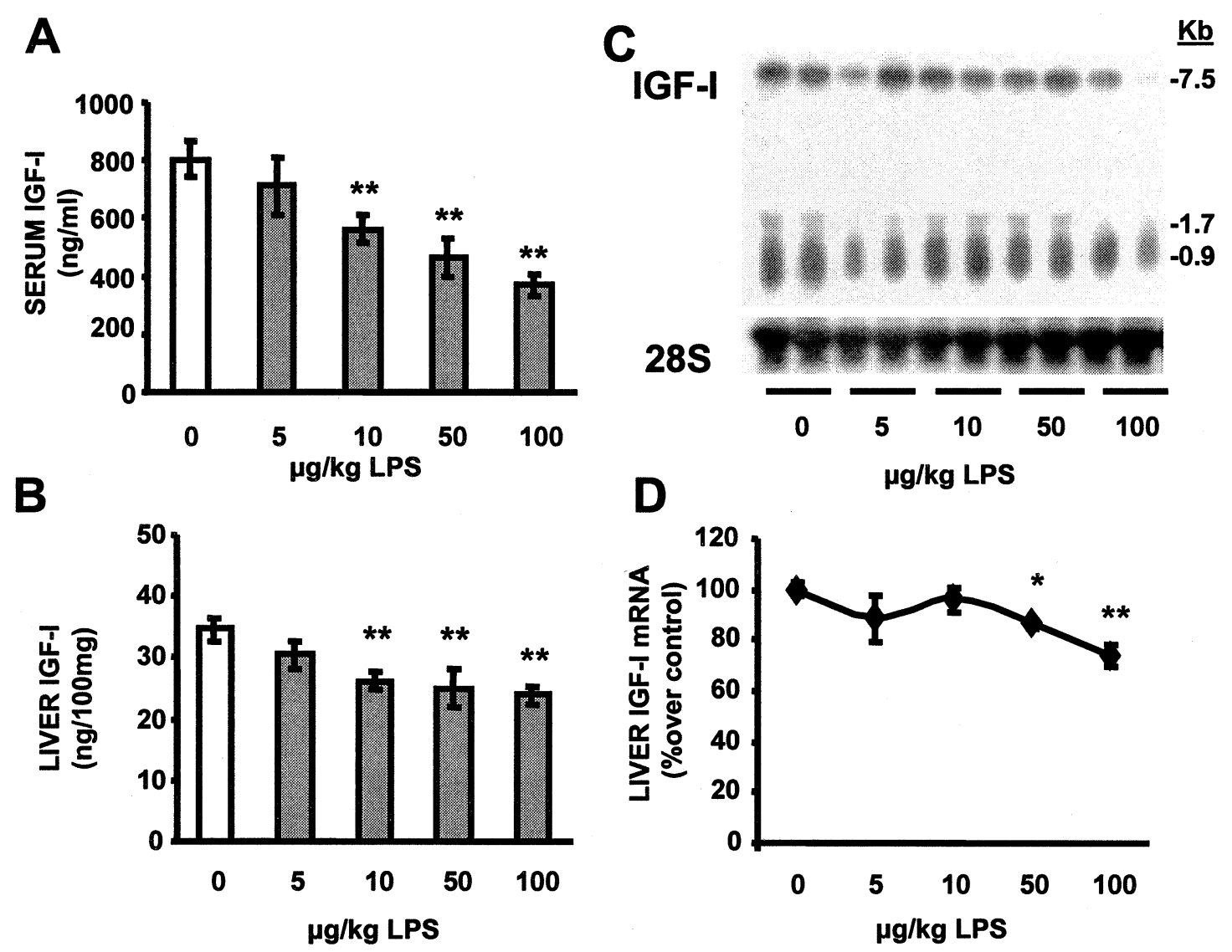

Figure 5 Effect of LPS administration at low doses (5, 10, 50 and $100 \mu \mathrm{g} / \mathrm{kg})$ on IGF-I concentrations in serum (A) and in the liver (B) and on liver IGF-I mRNA (D). (C) A representative Northern blot of IGF-I mRNA hybridization; $30 \mu \mathrm{g}$ total RNA were hybridized with an RNA probe for rat IGF-I mRNA, each lane corresponds to an individual animal from the indicated group and the $28 \mathrm{~S}$ ribosomal RNA is shown below. Detectable IGF-I mRNA species are indicated on the left and consist of a group of transcripts ranging of $7 \cdot 5,1 \cdot 7$ and $0.9 \mathrm{~kb}$. Because all these transcripts may potentially be translated to IGF-I, the densitometric results corresponded to the sum of the three IGF-I transcripts. Quantitative analyses of Northern blots are expressed as percentages of control rats injected with saline (D). Each bar represents the mean \pm S.E.M. for at least $7-10$ rats. ${ }^{*} P<0 \cdot 05,{ }^{*} P<0 \cdot 01$ vs control rats injected with saline.

Nevertheless, brain cytokines are also activated by peripheral LPS administration, even if the LPS dose is relatively low $(100 \mu \mathrm{g} / \mathrm{kg})$, showing a similar profile to central LPS administration (Turrin et al. 2001).

Taking into account that serum concentrations of IGF-I are decreased in rats injected with $10 \mu \mathrm{g} / \mathrm{kg}$ LPS, the possibility exists that the increase in pituitary $\mathrm{GH}$ synthesis and secretion would be secondary to the decrease in circulating IGF-I levels. However, the fact that somatotrope cells in culture respond to LPS by increasing GH release suggests that LPS in vivo has a stimulatory effect on the pituitary somatotrope cells independently of its effect on circulating IGF-I.

A stimulatory effect of LPS on GH synthesis and release has been described in pituitary cultures from animal species, different from rodents, such as sheep and pigs (Fry et al. 1998, Mainardi et al. 2002). In the pituitary, the folliculo-stellate cells are the source of cytokines, and
LPS-stimulated cells release interleukin (IL)-6 in the pituitary (Spangelo et al. 1990). As IL-1 and IL-6 have been reported to stimulate $\mathrm{GH}$ release in the rat pituitary (Bernton et al. 1987, Spangelo et al. 1989), the effect of LPS on GH secretion can be mediated by a stimulatory effect of one of those cytokines. It has recently been reported that the rodent pituitary can respond to an immune challenge (LPS or IL-1 i.p. administration) within a few minutes, and the main pituitary cells that respond to IL-1 are somatotrope and the folliculo-stellate cells (Parnet et al. 2003). However, these authors failed to find modifications in serum concentrations of $\mathrm{GH}$ or in its pituitary mRNA. One possible explanation could be the LPS dose, since they administered $10 \mu \mathrm{g}$ to mice of $30 \mathrm{~g}$, and this can be an intermediate dose that does not stimulate or inhibit pituitary GH.

The GH response to different LPS doses is different in vivo than in vitro. In the pituitary cells in vitro, we were 

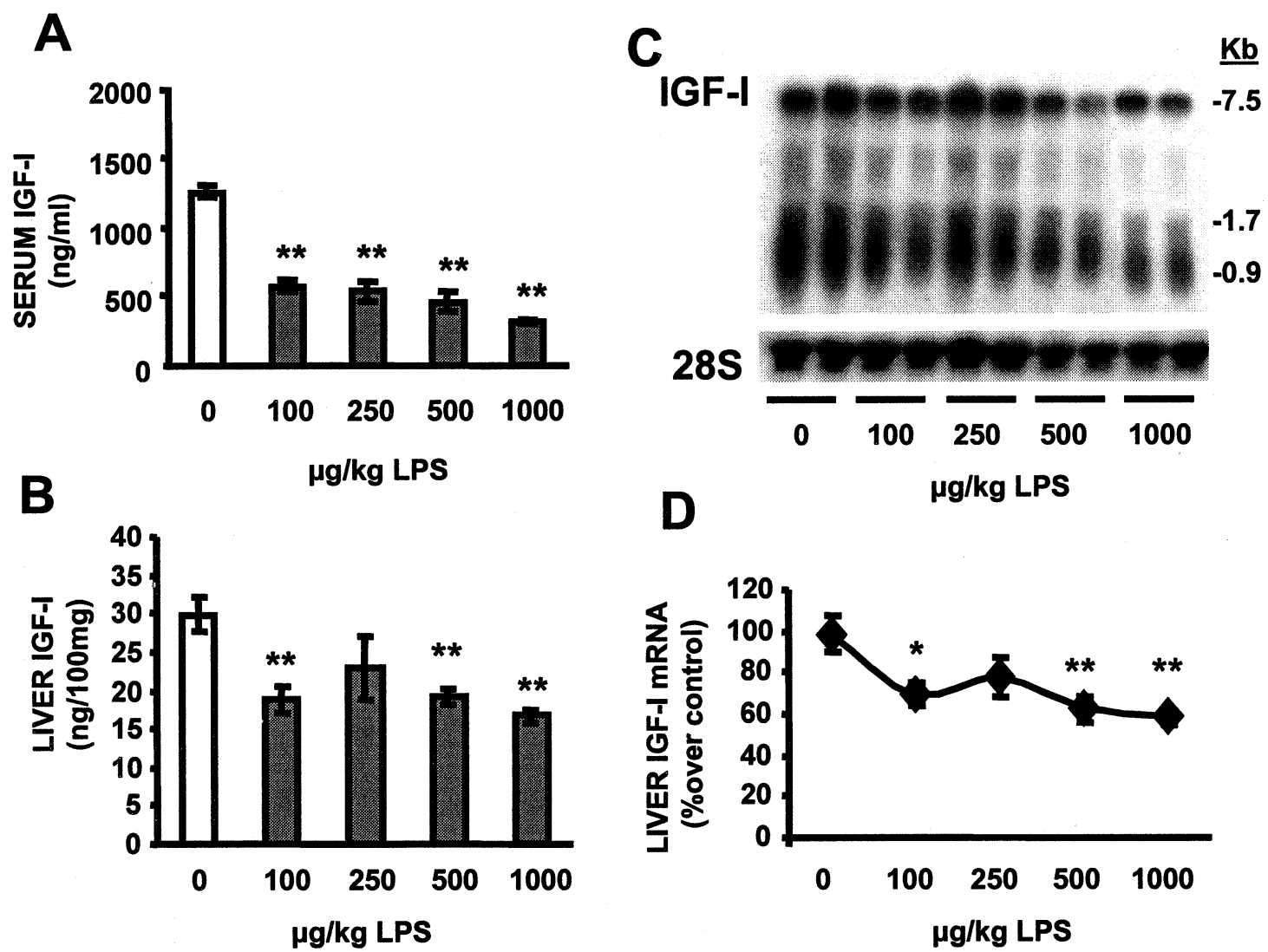

Figure 6 Effect of LPS administration at high doses (100, 250, 500 and $1000 \mu \mathrm{g} / \mathrm{kg}$ ) on serum and liver IGF-I concentration and on its gene expression in the liver. (A) Serum concentrations of IGF-I; values represent means \pm S.E.M. of 8-10 rats/group. (B) Liver IGF-l; values represents data from 9-10 rats/group. (C) A representative Northern blot analysis showing the $7.5,1.7$ and $0.9 \mathrm{~kb}$ IGF-I transcripts; the $28 \mathrm{~S}$ ribosomal RNA is shown below. (D) Liver IGF-I mRNA levels; the sum of the three IGF-I transcripts were quantified by densitometry and expressed as a percentage of the mean value in control rats treated with saline, $n=6-8$ rats. ${ }^{*} P<0 \cdot 05,{ }^{* *} P<0 \cdot 01$ vs control group.

unable to find a decrease in GH release, even with an LPS dose as high as $10 \mu \mathrm{g} / \mathrm{ml}$, whereas in vivo, LPS at high doses decreases serum concentrations of GH. This could be explained by the fact that at low LPS doses, the stimulatory effect on the pituitary GH prevails, whereas at higher LPS doses the increased release of somatostatin, or other hypothalamic modifications, inhibit GH secretion.

In rats, the inhibitory effect of LPS administration on GH release in vivo can be prevented by a somatostatin antiserum (Kasting \& Martin 1982), but this group was unable to find significant changes in somatostatin release in the median eminence after endotoxin administration (Fukata et al. 1985). However, chronic LPS administration to rats increased hypothalamic somatostatin content (Soto et al. 1998), and IL-1 is able to stimulate somatostatin release in primary neuron cultures (Scarborough et al. 1989), and in hypothalamic explants in vitro (Honegger et al. 1991). These data suggest that LPS stimulates hypothalamic somatostatin release leading to an inhibition of pituitary GH release. The LPS-induced inhibition of circulating $\mathrm{GH}$ does not seem to be mediated by $\mathrm{GH}-$ releasing hormone $(\mathrm{GHRH})$, since in vitro data suggest that both LPS and IL-1 stimulate hypothalamic GHRH release (Honegger et al. 1991, Peisen et al. 1995). Nevertheless, the possibility exists that the inhibitory effect of LPS on GH secretion could be also mediated by other central and/or peripheral factors different from somatostatin.

In the present study, the lack of an inhibitory effect of high LPS doses on GH mRNA, in spite of the decreased serum GH levels, suggests that LPS inhibits GH release but not GH synthesis. Another possibility is that we were unable to find modifications in pituitary GH mRNA for the time studied ( $18 \mathrm{~h}$ from the first LPS injection), since we observed that 8 days of LPS administration $(250 \mu \mathrm{g} / \mathrm{kg}$ daily) decreased pituitary GH content, indicating a decreased GH synthesis (Soto et al. 1998). Moreover, in adjuvant-induced arthritis, an experimental model of chronic inflammation, the decrease in serum concentrations of $\mathrm{GH}$ is associated with a decrease in $\mathrm{GH}$ gene expression in the pituitary (López-Calderón et al. 1999). 
A
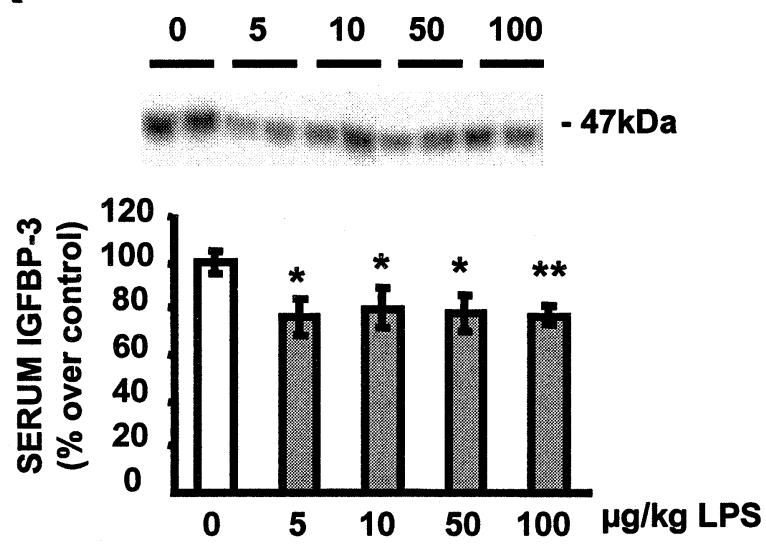

B
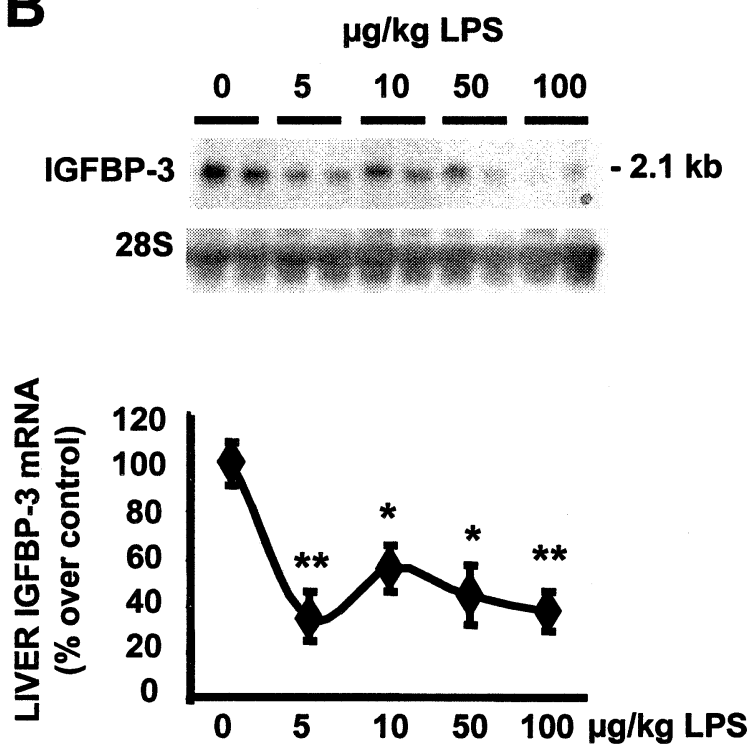

Figure 7 Effect of LPS administration at low doses (5, 10, 50 and $100 \mu \mathrm{g} / \mathrm{kg}$ ) on serum concentrations of IGFBP-3 and on liver IGFBP-3 mRNA. (A) Western ligand blot analysis and quantification of serum IGFBP-3. Serum IGFBP-3 was separated by SDS-PAGE on a $12.5 \%$ acrylamide gel, transferred to nitrocellulose, ligand blotted with ${ }^{125}$ I-IGF-I, and visualized via autoradiography. Data from 9-11 individual rats were quantified by densitometry and expressed as the percentage of the mean value in control rats injected with saline. (B) A representative Northern blot of IGFBP-3 mRNA hybridization of $30 \mu \mathrm{g}$ total liver RNA. The size of the hybridization band (in $\mathrm{kb}$ ) is indicated on the right; 28S, 28S ribosomal RNA. Quantitative analyses are expressed as percentages of control rats injected with saline, for $6-8$ rats per group. ${ }^{*} P<0 \cdot 05,{ }^{*} P<0 \cdot 01$ vs control group.

It has been proposed that the sepsis-induced decrease in IGF-I is associated with GH resistance. LPS administration decreases GHR gene expression in vitro and in vivo (Wolf et al. 1996, Defalque et al. 1999), and it is able to block the GH-responsive genes in the liver of hypophysectomized
A
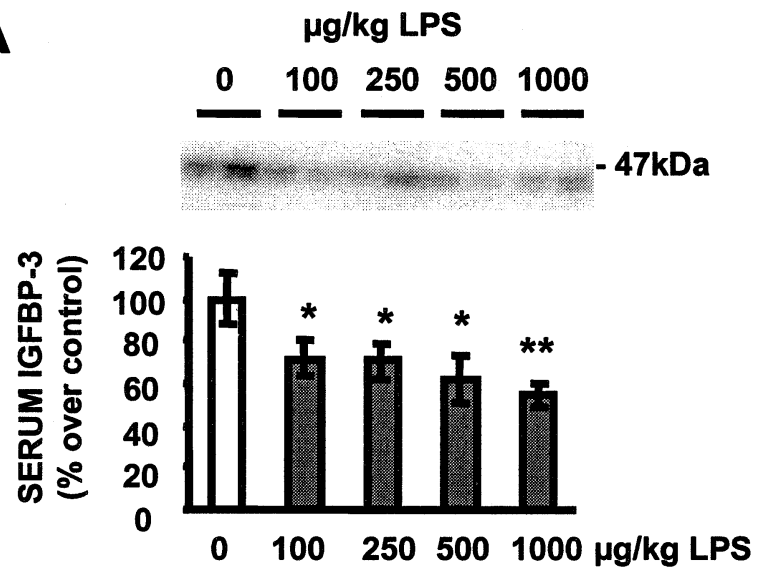

B
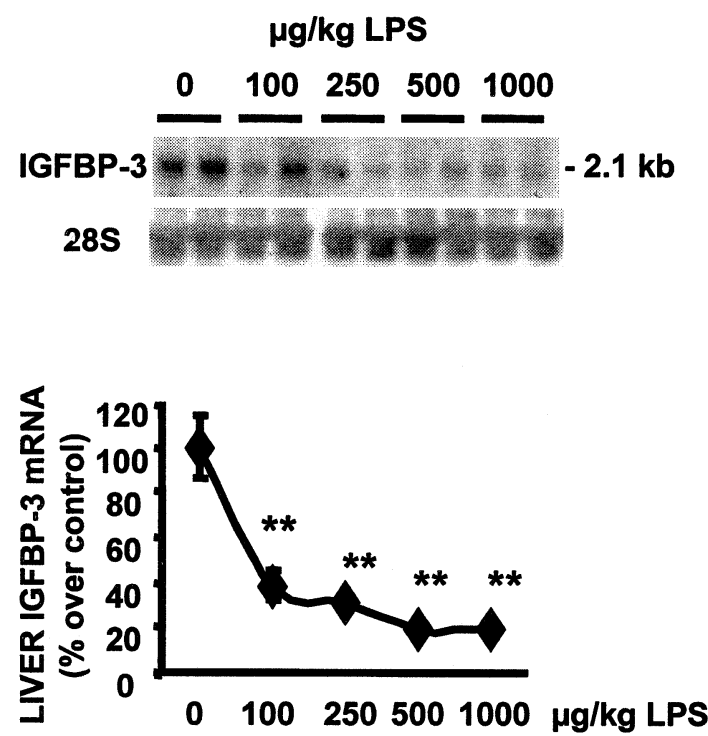

Figure 8 Effect of LPS administration at high doses (100, 250, 500 and $1000 \mu \mathrm{g} / \mathrm{kg}$ ) on serum concentrations of IGFBP-3 and on liver IGFBP-3 mRNA. (A) A representative Western ligand blot of IGFBP-3. Serum IGFBP-3 was separated by SDS-PAGE on a $12 \cdot 5 \%$ acrylamide gel, transferred to nitrocellulose, ligand blotted with ${ }^{125}$ I-IGF-I, and visualized via autoradiography. Data from 7-10 rats were quantified by densitometry and expressed as the percentage of the mean value in control rats injected with saline. LPS decreased circulating IGFBP-3. (B) A representative Northern blot of IGFBP-3 mRNA hybridization of $30 \mu \mathrm{g}$ total liver RNA. The size of the hybridization band (in $\mathrm{kb}$ ) is indicated on the right; 28S, 28S ribosomal RNA. Quantitative analyses are expressed as percentages of control rats injected with saline, for 7 or 8 rats per group. ${ }^{*} P<0 \cdot 05,{ }^{*} P<0 \cdot 01$ vs control group.

rats (Bergard et al. 2000). The effect of LPS on the GHR in the liver was not evident 3 or $6 \mathrm{~h}$ after administration of $1 \mathrm{mg} / \mathrm{kg}$ LPS, although it inhibits GH activation of Stat 5 (Mao et al. 1999, Denson et al. 2003). The authors concluded that the reduction in liver Stat5 activation was due to induction of postreceptor signaling inhibitors such 
as Cis and Socs-3 (Denson et al. 2003). However, when using a higher LPS dose $(7.5 \mathrm{mg} / \mathrm{kg})$ it was also possible to observe a significant reduction in GHR mRNA (Defalque et al. 1999). This is consistent with our data; the GHR mRNA in the liver does not decrease until $18 \mathrm{~h}$ after the dose of $100-250 \mu \mathrm{g} / \mathrm{kg}$, suggesting that at low LPS doses the inhibitory effect of LPS on IGF-I is mediated by a postreceptor $\mathrm{GH}$ signaling.

In our data, serum concentrations of IGF-I are more sensitive than the liver IGF-I or IGF-I mRNA to the inhibitory effect of LPS injection. Similarly, $6 \mathrm{~h}$ after IL-1 administration to rats, there was a $64 \%$ decrease in serum concentrations of IGF-I and a 32\% decrease in peptide content in the liver (Fan et al. 1996); the authors explained the difference as a rapid clearance of circulating IGF-I. Taking into account that IGFBP-3 is the major IGF-Ibinding protein in serum, the decrease in serum concentrations of IGFBP-3 may contribute to increasing IGF-I turnover and then to reducing IGF-I half-life in serum. This hypothesis is consistent with the data showing that IGF-I/IGFBP-3 binary complex administration to septic rats restores gastrocnemius protein synthesis to a rate comparable with that of control rats (Svanberg et al. 2000), suggesting that the binary complex administration accelerates protein synthesis by prolonging the availability of IGF-I. The binary complexes form a ternary complex with the acid-labile subunit (ALS), and endotoxin administration also induces a decrease in serum concentrations of ALS (Barreca et al. 1998, Kong et al. 2002). Then, the decrease in circulating IGFBP-3 and ALS might contribute to the decline in serum IGF-I observed after LPS administration.

In contrast, liver IGFBP-3 mRNA is more sensitive to the inhibitory effect of LPS than liver IGF-I mRNA. Among all variables we have measured, liver IGFBP-3 mRNA is the most affected by LPS administration at low doses. These data can be due to the fact that Kuppfer and endothelial cells are the main IGFBP-3-producing cells in the liver, and they would be very quickly activated by LPS stimulation, whereas the other liver cells synthesizing IGF-I, such as hepatocytes, would respond to a higher LPS dose than the Kuppfer cells. The present data are in accord with those we have previously reported in Lewis rats (Priego et al. 2003), in which the LPS-induced decrease in liver IGFBP-3 mRNA is GH- and IGF-I-independent.

The difference between the decrease in liver IGFBP-3 mRNA and the serum levels of IGFBP-3 after LPS administration is not due to alterations to its proteolysis, since we were unable to find any modifications in the serum IGFBP-3 proteolysis in any of the studied groups (data not shown). These data are in agreement with those we have previously reported using LPS at the dose of $1 \mathrm{mg} / \mathrm{kg}$ (Priego et al. 2003). Similarly, in another catabolic state, anorexia nervosa, the decrease in serum concentrations of IGFBP-3 is not associated with an increase in its proteolysis (Stoving et al. 1999). Taking into account that IGFBP-3 is also produced by other organs, it is possible that LPS stimulates IGFBP-3 production in other cells than in the liver. Accordingly, an increase in IGFBP-3 mRNA and protein in response to LPS stimulation in a human monocytic cell line has been reported (Agnese et al. 2002). Discordant serum IGFBP-3 concentrations and liver mRNA levels have been observed by Lemmey et al. (1997), and these authors propose that skin and fibroblast-type cells may be an important additional source of circulating IGFBP-3. All these data suggest that in addition to the liver, other IGFBP-3-synthesizing cells may contribute to the circulating pool of this protein.

In summary, our dose-response study provides new insights into the mechanisms by which LPS affects GHIGF-I-IGFBP. There is a dissociation between the effect of endotoxin on pituitary GH and the liver production of IGF-I and IGFBP-3. Initially, LPS at low doses may decrease liver IGF-I and IGFBP-3, whereas it potentiates pituitary GH secretion. This acute LPS response is similar to that described in the acute phase of critical illnesses in humans; there is an increased activity of the anterior pituitary and a peripheral decrease of the anabolic hormones (Van den Berghe 2002). At high LPS doses, the decrease in liver and serum IGF-I and IGFBP-3 is concomitant with decreased serum concentrations of $\mathrm{GH}$ and GHR mRNA in the liver.

\section{Acknowledgements}

The authors are indebted to A Carmona for technical assistance and to C Bickart for the English correction of the manuscript. We are grateful to the US National Institute of Diabetes, Digestive and Kidney Diseases, National Hormone and Pituitary Program for the reagents for GH and IGF-I determinations.

\section{Funding}

This work was supported by a grant from Fondo de Investigaciones Sanitarias de la Seguridad Social (FISS 00/0949) and a Fellowship to T P (FPU, AP2001-0053).

\section{References}

Agnese DM, Calvano JE, Hahm SJ, Calvano SE \& Lowry SF 2002 Insulin-like growth factor binding protein-3 is upregulated in LPS-treated THP-1 cells. Surgical Infections 3 119-125.

Albiston AL \& Herington AC 1990 Cloning and characterization of the growth hormone-dependent insulin-like growth factor binding protein (IGFBP-3) in the rat. Biochemical and Biophysical Research Communications 166 892-897.

Barreca A, Ketelslegers JM, Arvigo M, Minuto F \& Thissen JP 1998 Decreased acid-labile subunit (ALS) levels by endotoxin in vivo and by interleukin-1 beta in vitro. Growth Hormone and IGF-I Research $\mathbf{8}$ 217-223. 
Baumbach WR, Horner DL \& Logan JS 1989 The growth hormonebinding protein in rat serum is an alternatively spliced form of the rat growth hormone receptor. Genes and Development 3 1199-1205.

Bergard PL, Schwarzenberg SJ, Humbert JT, Morrison M, Amarashinge S, Towle HC \& Berry SA 2000 Inhibition of growth hormone action in models of inflammation. American Journal of Physiology. Cell Physiology 279 C1906-C1917.

Bernton EW, Beach JE, Holaday JW, Smallridge RC \& Fein HG 1987 Release of multiple hormones by a direct action of interleukin-1 on pituitary cells. Science 238 519-521.

Briard N, Dadoun F, Pommier G, Sauze N, Lebouc Y, Oliver C \& Dutour A 2000 IGF-I/IGFBPs system response to endotoxin challenge in sheep. Journal of Endocrinology 164 361-369.

Coleman ES, Elsasser TH, Kemppainen RJ, Coleman DA \& Sartin JL 1993 Effect of endotoxin on pituitary hormone secretion in sheep. Neuroendocrinology 58 111-122.

Dahn MS, Lange P \& Jacobs LA 1988 Insulin-like growth factor I production is inhibited in human sepsis. Archives of Surgery 123 1409-1414.

Daniel JA, Whitlock BK, Wagner CG \& Sartin JL 2002 Regulation of the growth hormone and luteinizing hormone response to endotoxin in sheep. Domestic Animal Endocrinology 23 361-370.

Defalque D, Brandt N, Ketelslegers J-M \& Thissen J-P 1999 GH insensitivity induced by endotoxin injection is associated with decreased liver receptors. American Journal of Physiology 276 E565-E572.

Denson LA, Held MA, Menon RK, Frank SJ, Parlow AF \& Arnold DL 2003 Interleukin-6 inhibits hepatic growth hormone signaling via upregulation of Cis and Socs-3. American Journal of Physiology. Gastrointestinal and Liver Physiology 284 G646-G654.

Fan J, Molina PE, Gelato M \& Lang CH 1994 Differential tissue regulation of insulin-like growth factor-I content and binding proteins after endotoxin. Endocrinology 134 1685-1692.

Fan J, Wojnar MM, Theodorakis M \& Lang CH 1996 Regulation of insulin growth factor (IGF)-I mRNA and peptide and IGF-binding proteins by interleukin-1. American Journal of Physiology 270 R621-R629.

Fry CL, Gunter DR, McMahon CD, Steele B \& Sartin JL 1998 Cytokine-mediated growth hormone release from cultured ovine pituitary cells. Neuroendocinology 68 192-200.

Fukata J, Kasting NW \& Martin JB 1985 Somatostatin release from the median eminence of unanesthetized rats: lack of correlation with pharmacologically suppressed growth hormone secretion. Neuroendocrinology 40 193-200.

Hevener W, Almond GW, Armstrong JD \& Richards RG 1997 Effects of acute endotoxemia on serum somatotropin and insulinlike growth factor I concentrations in prepubertal gilts. American Journal of Veterinary Research 58 1010-1013.

Honegger J, Spagnoli A, D’Urso R, Navarra P, Tsagarakis S, Besser GM \& Grossman AB 1991 Interleukin-1B modulates the acute release of growth hormone-releasing hormone and somatostatin from rat hypothalamus in vitro, whereas tumor necrosis factor and interleukin-6 have no effect. Endocrinology 129 1275-1282.

Karima R, Matsumoto S, Higashi H \& Matsushima K 1999 The molecular pathogenesis of endotoxic shock and organ failure. Molecular Medicine Today 5 123-132.

Kasting NW \& Martin JB 1982 Altered release of growth hormone and thyrotropin induced by endotoxin in the rat. American Journal of Physiology 243 E332-E337.

Kong S-E, Firth SM, Baxter RC \& Delhanty PJD 2002 Regulation of the acid-labile subunit in sustained endotoxemia. American Journal of Physiology 283 E692-E701.

Lang CH, Pollard V, Fan J, Traber L, Traber DL, Frost RA, Gelato MC \& Prough DS 1997 Acute alterations in growth hormone-insulinlike growth factor axis in humans injected with endotoxin. American Journal of Physiology 273 R371-R378.

Lemmey AB, Glassford J, Flick-Smith HC, Holly JMP \& Pell JM 1997 Differential regulation of tissue insulin-like growth factor- binding protein (IGFBP)-3, IGF-I and IGF type receptor mRNA levels, and serum IGF-I and IGFBP concentrations by growth hormone and IGF-I. Journal of Endocrinology 154 319-328.

López-Calderón A, Soto L \& Martín AI 1999 Chronic inflammation inhibits GH secretion and alters the serum insulin-like growth factor system in rats. Life Sciences 65 2049-2060.

Mainardi GL, Saleri R, Tomanini C \& Baratta M 2002 Effects of interleukin-1-beta, interleukin-6 and tumor necrosis factor-alpha, alone or in association with hexarelin or galanin, on growth hormone gene expression and growth hormone release from pig pituitary cells. Hormone Research 58 180-186.

Mao Y, Ling P-R, Fitzgibbons TP, McCowen KC, Frick GP, Bistrian BR \& Smith RJ 1999 Endotoxin-induced inhibition of growth hormone receptor signalling in rat liver in vivo. Endocrinology 140 $5505-5515$.

O'Leary MJ, Quinton N, Ferguson CN, Preedy VR, Ross RJM \& Hinds CJ 2000 In rats with sepsis, the acute fall in IGF-I is associated with an increase in circulating growth hormone-binding protein levels. Intensive Care Medicine 26 1547-1552.

Parnet P, Pousset F \& Laye S 2003 NFKB activation in mouse pituitary: comparison of response to interleukin $-1 \beta$ and lipopolysaccharide. Journal of Neuroendocrinology 15 304-314.

Peisen JN, McDonnell KJ, Mulroney SE \& Lumpkin MD 1995 Endotoxin-induced suppression of the somatotropic axis is mediated by interleukin-1 $1 \beta$ and corticotropin-releasing factor in the juvenile rats. Endocrinology 136 3378-3390.

Peter HS, Shine J, Martial JA, Baxter JD \& Goodman HM 1977 Nucleotide sequence and amplification in bacteria of structural gene for rat growth hormone. Nature 270 486-494.

Priego T, Ibáñez de Cáceres I, Martín AI, Villanúa MA \& López-Calderón A 2002 Glucocorticoids are not necessary for the inhibitory effect of endotoxic shock on serum insulin-like growth factor (IGF)-I and hepatic IGF-I messenger RNA. Journal of Endocrinology 172 449-456.

Priego T, Ibáñez de Cáceres I, Martín AI, Villanúa MA \& López-Calderón A 2003 Endotoxin decreases serum IGFBP-3 and liver IGFBP-3 mRNA: comparison between Lewis and Wistar rats. Molecular and Cellular Endocrinology 199 23-28.

Roberts CT, Lasky SR, Lowe WL, Seaman WT \& LeRoith D 1987 Molecular cloning of rat insulin-like growth factor I complementary deoxyribonucleic acids: differential messenger ribonucleic acid processing and regulation by growth hormone in extra hepatic tissues. Molecular Endocrinology 1 243-248.

Scarborough DE, Lee SL, Dinarello CA \& Reichim S 1989 Interleukin-1 beta stimulates somatostatin biosynthesis in primary cultures of fetal rat brain. Endocrinology 124 549-551.

Soto L, Martín AI, Millán S, Vara E \& López-Calderón A 1998 Effects of endotoxin lipopolysaccharide administration on the somatotropic axis. Journal of Endocrinology 159 239-246.

Spangelo BL, Judd AM, Isakson PC \& McLeod RM 1989 Interleukin-6 stimulates anterior pituitary hormone release in vitro. Endocrinology 125 575-577.

Spangelo BL, MacLeod RM \& Isakson PC 1990 Production of interleukin-6 by anterior pituitary cells in vitro. Endocrinology 126 582-586.

Stoving RK, Flyvbjerg A, Frystyk J, Fisker S, Hangaard J, Hasen-Nord M \& Hagen C 1999 Low serum levels of free and total insulin-like growth factor I (IGF-I) in patients with anorexia nervosa are not associated with increased IGF-binding protein-3 proteolysis. Journal of Clinical Endocrinology and Metabolism $\mathbf{8 4}$ 1346-1350.

Svanberg E, Frost RA, Lang CH, Isgaard J, Jefferson LS, Kimball SR \& Vary TC 2000 IGF-I/IGFBP-3 binary complex modulates sepsis-induced inhibition of protein synthesis in skeletal muscle. American Journal of Physiology 279 E1145-E1158.

Turrin NP, Gayle D, Ilyin SE, Flynn MC, Langhans W, Schwart G] \& Plata-Salaman CR 2001 Proinflammatory cytokine mRNA 
induction in the periphery and brain following intraperitoneal administration of bacterial lipopolysaccharide. Brain Research Bulletin 54 443-453.

Van den Berghe 2002 Dynamic neuroendocrine responses to critical illness. Frontiers in Neuroendocrinology 23 370-391.

Wolf M, Böhm S, Brand M \& Kreymann G 1996 Proinflammatory cytokines interleukin 1 beta and tumor necrosis factor alpha inhibit growth hormone stimulation of insulin-like growth factor I synthesis and growth hormone receptor mRNA levels in cultured rat liver cells. European Journal of Endocrinology 135 729-737.

Received 26 June 2003

Accepted 10 July 2003

Made available online as an

Accepted Preprint 11 July 2003 